\title{
PENGELOLAAN PENGADUAN MASYARAKAT MODEL CROWDSOURCING MENGGUNAKAN LAYANAN BERBASIS LOKASI (STUDI KASUS PEMERINTAH KABUPATEN GIANYAR)
}

\author{
I Made Sunia Raharja ${ }^{1)}$, Anak Agung Ketut Agung Cahyawan Wiranatha ${ }^{2)}$ \\ 1), 2) Program Studi Teknologi Informasi, Fakultas Teknik, Universitas Udayana \\ Jl. Raya Kampus UNUD, Bukit Jimbaran, Kuta Selatan, Badung-Bali-803611 \\ Email : sunia.raharja@unud.ac.id ${ }^{1)}$, agung.cahyawan@unud.ac.id ${ }^{2)}$
}

\begin{abstract}
Abstrak
Teknologi Smart City yang memanfaatkan komunitas dalam jaringan, memungkinkan terciptanya kolaborasi dan peningkatan keterlibatan masyarakat. Model Crowdsourcing memberikan fasilitas penerimaan keluhan, umpan balik, usulan dan ide dari banyak orang kepada suatu organisasi. Dengan model Crowdsourcing pemerintah kota dapat menerima pengaduan, masukan dan saran secara kolektif dari masyarakat kota. Selama ini pengaduan masyarakat di kabupaten Gianyar masih menggunakan sistem yang sangat sederhana. Data-data yang diambil masih dalam bentuk teks yang kurang informatif sehingga menghambat koordinasi antar instansi terkait untuk menindaklanjuti masalah yang terjadi di lingkungan masyarakat kota. Pengelolaan pengaduan masyarakat melalui Sistem informasi pengaduan masyarakat model Crowdsourcing menggunakan layanan berbasis lokasi dapat mengumpulkan data-data pengaduan masyarakat dengan lebih efisien dan lebih informatif karena dilengkapi data pendukung dalam bentuk media gambar dan koordinat lokasi. Hasil pengujian UAT menunjukkan 95\% pengguna masyarakat dan 80\% pengguna pejabat pemangku kepentingan pelayanan publik dapat menggunakan fungsi dari sistem informasi pengaduan masyarakat dengan baik. Permasalahan terjadi pada fungsi yang berkaitan dengan koordinat lokasi pengaduan yang tidak akurat dan masalah jaringan Internet.
\end{abstract}

Kata kunci: Smart City, Crowdsourcing, Pengaduan Masyarakat, Sistem Informasi Geografis, layanan berbasis lokasi.

\begin{abstract}
Smart City technology that utilizes communities in the network enables collaboration and increased community involvement. The Crowdsourcing Model provides an organization to receive complaints, feedback, proposals, and ideas from many people. With the Crowdsourcing model, the city government can receive complaints, input, and suggestions collectively from the city community. So far, public complaints in the district of Gianyar still use a straightforward system. The data taken is still in the form of text that is less informative so that it inhibits coordination between relevant agencies to follow up on problems that occur in the city community. Management of public complaints through the Crowdsourcing model's public complaint information system using location-based services can collect community complaints data more efficiently and more informative because it is equipped with supporting data in the form of image media and location coordinates. UAT test results show that $95 \%$ of public users and $80 \%$ of public service stakeholder users can use the function of the civil complaint information system properly. Problems occur with features relating to the inaccurate coordinates of the location of complaints and Internet network problems.
\end{abstract}

Keywords : Smart City, Crowdsourcing, Public Complaints, Geographic Information System, location based services.

\section{PENDAHULUAN}

Teknologi Smart City yang memanfaatkan komunitas dalam jaringan, memungkinkan terciptanya kolaborasi dan peningkatan keterlibatan masyarakat. Hal ini dapat memberikan pengaruh positif pada kehidupan kota yang semakin dinamis. Model Crowdsourcing memberikan 
fasilitas penerimaan keluhan, umpan balik, usulan dan ide dari banyak orang kepada suatu organisasi. Dengan model Crowdsourcing pemerintah kota dapat menerima pengaduan, masukan dan saran secara kolektif dari masyarakat kota. Informasi pengaduan masyarakat yang terkelola dengan baik dapat membantu pemerintah kota dalam memberikan pelayanan publik yang lebih optimal.

Layanan berbasis lokasi dapat memberikan informasi koordinat geografik lokasi di peta. Data koordinat lokasi sangat penting disertakan dalam informasi pengaduan masyarakat, data koordinat lokasi membantu pemangku kepentingan untuk menindaklanjuti pengaduan masyarakat. Dengan mengetahui lokasi dari tindakan pengaduan masyarakat, pemangku kepentingan dapat mempertimbangkan penanganan dari pengaduan masyarakat dengan lebih optimal.

Melihat dari keuntungan yang bisa didapatkan dari layanan berbasis lokasi, maka akan dilakukan pengelolaan data-data pengaduan masyarakat melalui rancang bangun sistem informasi pengaduan masyarakat menggunakan model Crowdsourcing yang dilengkapi dengan layanan berbasis lokasi.

Pengaduan masyarakat sangat dibutuhkan oleh pemerintah untuk mengukur keberhasilan dalam memberikan pelayanan publik. Informasi pengaduan dari masyarakat menjadi elemen penting sebagai referensi untuk memperbaiki kekurangan dari pelayanan publik yang sudah dilaksanakan[5]. Sebuah sistem informasi pengaduan masyarakat juga dibutuhkan tidak hanya pada instansi pemerintahan sebagai pendukung tata kelola birokrasi, melainkan juga pada bidang kesejahteraan sosial seperti yang dilakukan oleh Anofrizen (2017) yang mengembangkan sistem informasi pengaduan masyarakat untuk program keluarga harapan kota Pekanbaru. Sistem informasi dibuat untuk mengelola data yang sebelumnya dilakukan secara manual dan dalam bentuk hardcopy menjadi database yang dapat diakses melalui aplikasi berbasis Web. Pengembangan backend sistem menggunakan UML, sedangkan frontend sistem menggunakan PHP[1].

Sebuah survei telah dilakukan oleh Susanto, Diani dan Hafidz (2018) untuk mengetahui penerimaan masyarakat terhadap penggunaan sistem informasi pengaduan masyarakat. Dari survei diketahui bahwa ada dua faktor yang dapat dinilai setelah menggunakan sistem pengaduan masyarakat City133, yaitu kemudahan penggunaan aplikasi(Perceived Ease Of Use) dan kemanfaatan penggunaan aplikasi(Perceived Usefulness) [8].

Rakhmawati (2016) mengembangkan aplikasi mobile untuk meningkatkan partisipasi masyarakat dalam menjaga lingkungan kota. Masyarakat kota diharapkan lebih aktif dalam menyampaikan permasalahan yang terjadi di lingkungannya masing-masing. Untuk memfasilitasi hal tersebut, dibuat aplikasi yang memungkinkan masyarakat melaporkan permasalahan tersebut secara efektif dan efisien[6].

\section{DASAR TEORI}

\section{a. Model Crowdsourcing}

Crowdsourcing adalah model produksi dan penyelesaian permasalahan yang terdistribusi dan dilakukan dalam jaringan. Model ini diciptakan oleh Howe dan Mark Robinson pada tahun 2006, yang dideskripsikan sebagai model bisnis baru berbasis web yang memanfaatkan solusi kreatif dari individu-individu dalam suatu jaringan terdistribusi melalui penerimaan sukarelawan yang terbuka[3].

b. Sistem informasi Crowdsourcing

Sistem informasi dengan model crowdsourcing dapat dikelompokkan menjadi empat kelompok berdasarkan target masalahnya[7].

- Manajemen pengetahuan secara kolektif.

Sistem dengan tipe ini memungkinkan untuk membangun dan mendapatkan pengetahuan dengan menggabungkan masukan-masukan dari pengguna sistem

- Kreatifitas secara kolektif.

Pekerjaan yang membutuhkan kreativitas hanya dapat dilakukan oleh manusia. Crowdsourcing digunakan untuk masuk kedalam komunitas yang terdiri dari ribuan pengguna untuk mengembangkan produk dalam bidang seni dan desain 
- Bermain secara kolektif.

Dengan mengambil keuntungan dari keinginan manusia yang suka dihibur, masalah dapat diselesaikan secara efektif dan efisien melalui permainan dalam jaringan

- Pemungutan suara secara kolektif.

Pada tipe sistem Crowdsourcing ini pengguna diminta untuk menjawab pertanyaan dari beberapa pilihan. Jawaban yang paling banyak dipilih oleh pengguna dianggap jawaban yang benar.

c. Layanan Berbasis Lokasi

Posisi digambarkan berbentuk koordinat spasial, koordinat spasial direpresentasikan sebagai sebuah titik seperti pada koordinat cartesian. Lokasi berkaitan dengan tempat tertentu di dunia nyata, jika penentuan posisi menghasilkan lokasi spasial, penentuan posisi akan dipetakan pada deskripsi lokasi tertentu agar bisa diinterpretasikan oleh pengguna Layanan Berbasis Lokasi(Location Based Service) atau LBS. Location Service(LCS) berurusan dengan lokalisasi target tertentu, kemudian membuat hasil data hasil lokasi dapat diakses oleh pihak eksternal dan bertanggung jawab untuk menghasilkan dan mengirimkan data lokasi. LBS adalah layanan yang menambah nilai dari suatu target lokasi yang disediakan oleh LCS. Dengan menggunakan pengetahuan dari perangkat bergerak(Mobile device) LBS memberikan hasilnya ke pelanggan atau pihak ketiga.

\section{METODOLOGI PENELITIAN}

a. Analisis Data

Pada tahap ini dilakukan wawancara, analisis, observasi dan pengamatan terhadap masalah-masalah penyampaian pengaduan masyarakat yang terjadi di pemerintah daerah kabupaten Gianyar. Mempelajari dan menganalisis solusi-solusi yang dilakukan dalam beberapa peneliti sebelumnya, dalam hal memfasilitasi pengaduan masyarakat melalui sistem informasi pengaduan masyarakat.

Setelah memahami masalah-masalah yang terjadi dan solusi-solusi yang diterapkan, akan ditentukan spesifikasi fungsional dari sistem informasi pengaduan masyarakat yang nantinya akan menjadi fitur-fitur dalam sistem informasi pengaduan masyarakat yang dikembangkan. Menentukan spesifikasi data yang berisi data-data apa saja yang digunakan sebagai input dan informasi sebagai keluaran dari sistem informasi pengaduan masyarakat.

Agar dapat melanjutkan penelitian ke tahapan selanjutnya pada tahapan ini juga dilakukan pemahaman tentang model crowdsourcing sebagai model untuk memfasilitasi masalah-masalah pengaduan masyarakat. Mempelajari teknologi Location Base Service(LBS) yang akan digunakan dalam proses pengembangan sistem informasi.

b. Perancangan Sistem

Data-data yang didapatkan pada tahap analisis direpresentasikan dalam bentuk diagram Data Flow Diagram(DFD) untuk informasi mengenai spesifikasi fungsional dan prosedurprosedur yang diterapkan dalam sistem. Spesifikasi data direpresentasikan dalam bentuk Entity Relationship Diagram(ERD) dan Physical Data Model(PDM).

c. Implementasi Sistem

Membangun sistem informasi berdasarkan hasil yang diperoleh dari tahapan perancangan sistem. Membangun infrastruktur sistem model crowdsourcing menggunakan layanan Berbasis Lokasi(LBS).

d. Pengujian Sistem

Pengujian yang dilakukan pada sistem informasi adalah pengujian fungsionalitas sistem untuk memastikan semua fungsionalitas yang dibuat sudah berjalan dengan sebagaimana mestinya. Pengujian User Acceptance Test dilakukan untuk mengetahui bahwa penggunaan sistem sudah dapat menyelesaikan permasalahan pengaduan masyarakat dan mencapai tujuan penelitian.

Berisi landasan teori yang relevan. Disajikan secara sistematik sehingga didapatkan gambaran tentang dasar pembuatan makalah ini dan hasil yang diharapkan

Alur metode penelitian ditunjukkan pada Gambar 1. 


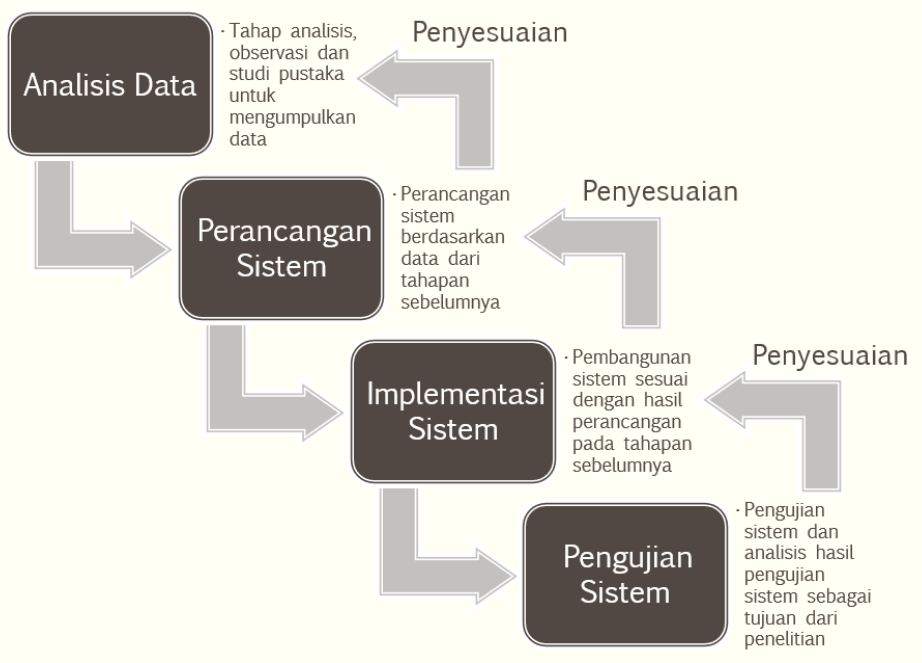

Gambar 1. Alur Metode Penelitian

\section{HASIL DAN PEMBAHASAN}

a. Pengujian dan Pembahasan Tahapan Analisis Data

Pengaduan masyarakat selama ini disatukan dengan penyampaian kritik dan saran yang dapat disampaikan melalui website resmi kabupaten Gianyar di alamat https://gianyarkab.go.id/index.php/kirim-saran/, data-data yang diperlukan diantaranya adalah :

- Nama

- Alamat

- Email

- Topik

- Saran/Pengaduan

- Tanggapan

Untuk mendapatkan data yang lebih informatif diperlukan tambahan jenis data lainya seperti misalnya foto dan data dari layanan berbasis lokasi. Sehingga spesifikasi data yang diperlukan untuk sistem informasi pengaduan masyarakat diantaranya adalah :

- Nama

- Alamat

- Email

- Topik

- Saran/Pengaduan

- Data lokasi(koordinat Peta)

- Bukti fisik berupa foto

- Status(sudah ditanggapi atau belum)

- Deskripsi tanggapan

Secara umum sistem informasi pengaduan masyarakat dapat melakukan beberapa fungsi, diantaranya adalah :

- Submit data pengaduan

- Melihat data pengaduan

- Melihat rangkuman data pengaduan

Model sistem informasi crowdsourcing yang digunakan adalah untuk memanajemen pengetahuan secara kolektif dengan memanfaatkan keterlibatan masyarakat secara sukarela. Layanan berbasis lokasi yang digunakan adalah sistem informasi geografis peta(MAPS API) yang diintegrasikan dengan sistem informasi pengaduan.

b. Pengujian dan Pembahasan Tahapan Perancangan Sistem 
Hasil dari tahapan perancangan sistem adalah gambar DFD sebagai perancangan spesifikasi fungsional sistem, dan gambar tabel sebagai perancangan spesifikasi data sistem. Gambar 2 menunjukkan diagram DFD spesifikasi fungsional sistem.

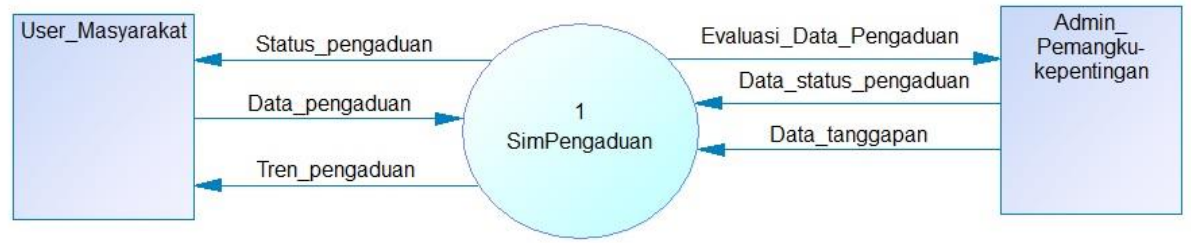

Gambar 2. Perancangan Spesifikasi Fungsional

Perancangan spesifikasi data terdiri dari 2 buah tabel yang ditunjukkan pada gambar 3 .

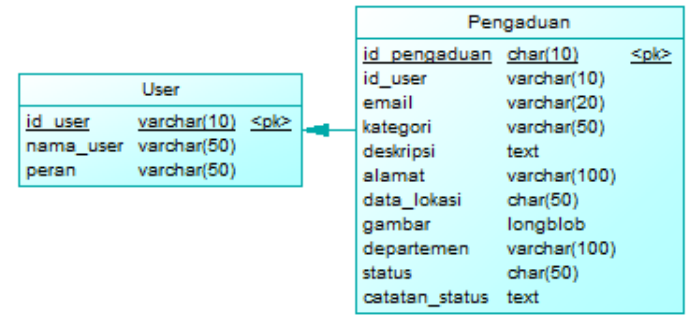

Gambar 3. Perancangan Spesifikasi Data

c. Pengujian dan Pembahasan Tahapan Implementasi Sistem

Pada tahap ini dilakukan pengembangan sistem model crowdsourcing yang berbasis cloud dan menggunakan layanan Berbasis Lokasi(LBS). Implementasi sistem informasi model crowdsourcing untuk memanajemen pengetahuan secara kolektif membutuhkan lingkungan kolaboratif(collaborative environment), sebuah lingkungan kolaboratif dapat berbentuk suatu perangkat lunak kolaboratif(collaborative software).

Sebuah Content Management System(CMS) mendukung banyak user dalam suatu lingkungan kolaboratif(collaboratif environment)[4]. CMS dapat digunakan untuk mengelola pembuatan dan modifikasi konten digital[2]. Salah satu CMS yang populer digunakan adalah Drupal. Sistem informasi pengaduan masyarakat model crowdsourcing menggunakan cloud dan layanan berbasis lokasi diimplementasikan menggunakan Drupal 8.

1) Implementasi Spesifikasi Fungsional

Implementasi proses menggunakan Drupal dilakukan dengan mengelola form-form atau view sehingga dapat memasukkan dan menampilkan data-data yang dibutuhkan dalam spesifikasi data. Implementasi submit data pengaduan ditunjukkan pada gambar 4.

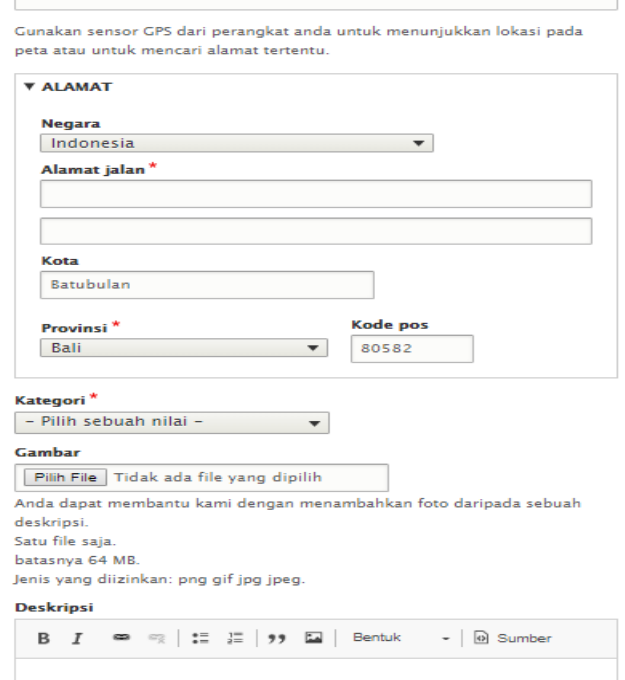

Gambar 4. Implementasi fungsi submit data pengaduan Implementasi melihat data pengaduan ditunjukkan pada gambar 5. 

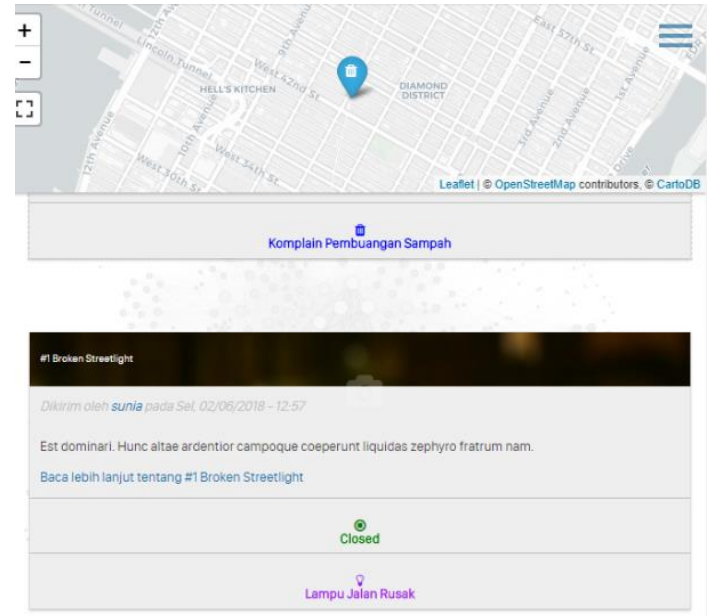

Gambar 5. Implementasi fungsi melihat data pengaduan Implementasi melihat rangkuman data pengaduan ditunjukkan pada gambar 6.

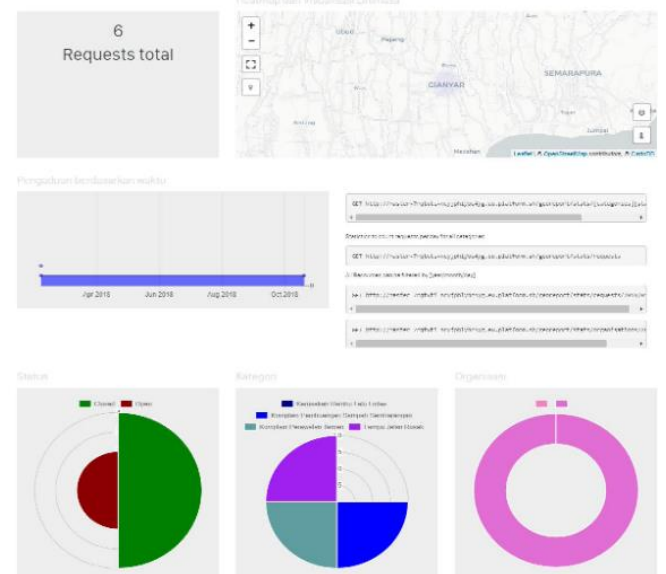

Gambar 6. Implementasi fungsi melihat rangkuman data pengaduan

2) Implementasi Spesifikasi data

Implementasi spesifikasi data dilakukan dengan mengelola database konten pada Drupal 8. Gambar 7 menunjukkan implementasi tabel user, sedangkan gambar 8 adalah implementasi tabel pengaduan.

\begin{tabular}{|c|c|c|c|c|c|c|}
\hline$\square$ & NAMA PENGGUNA & STATUS & PERAN & ANGGOTA SELAMA & • & AKSES TERAKHIR \\
\hline$\square$ & api_user & Aktif & & 1 pekan 4 hari & & tidak pernah \\
\hline$\square$ & sunia & Aktif & - Administrator & 1 pekan 4 hari & & 11 menit 29 detik ago \\
\hline
\end{tabular}

Gambar 7. Implementasi spesifikasi data tabel user

\begin{tabular}{|c|c|c|c|c|c|c|c|}
\hline 3 & JuDut. & JENIS KONTEN & PENULUS & STATUS & DIPERRAHARUI & OPERASI- OF & ERASI \\
\hline ] & 311 dry Service & Halaman dasar & sunia & nipublikasikan & $08 / 03 / 2018-08: 26$ & Sunting & - \\
\hline 0 & ol Eroken Streetight & Service Request & sunia & Dipubilkasıkan & $07 / 26 / 2018-15: 17$ & Sunting & - \\
\hline 3 & 24 Litter Rasker Compiaint & Servire flenilest & suria & Dipublikasikan & $07 / 26 / 2018-15: 17$ & Sunting & - \\
\hline 3 & t3 Fark Maintenance Complaint & Service Request & suria & Dipubilkasikan & $07 / 26 / 2018-15: 17$ & Sunting & $=$ \\
\hline & As Park Maintenance Compiaint & Service Request & suria & Dipublikasikan & $07 / 26: 2018-15.17$ & Suntiny & - \\
\hline & t2 Eroken Strestight & Serves Request & sunia & Dipubilkaslkan & $07 / 20 / 2018-15: 17$ & Sunting & - \\
\hline
\end{tabular}

Gambar 8. Implementasi tabel pengaduan 
d. Pengujian dan Pembahasan Tahapan Pengujian Sistem

Dilakukan pengujian sistem dalam bentuk User Acceptance Test(UAT). Pengujian UAT bertujuan untuk mendapatkan validasi bahwa penggunaan sistem sudah dapat memenuhi semua spesifikasi fungsional yang ditentukan dalam tahap perancangan sistem. Pengujian dilakukan dengan memberikan pertanyaan setelah 45 orang pengguna dan mencoba sistem informasi pengaduan. Semua spesifikasi fungsionalitas sistem diuji coba kepada pengguna sehingga didapatkan pengalaman penggunaan(User Experience). Tabel 1 menunjukkan pengujian fungsional sistem pada User Acceptance Test).

40 orang pengguna adalah masyarakat yang datang ke kantor pemerintah daerah kabupaten Gianyar di Jln. Ngurah Rai No. 5 - 7 Gianyar, Bali. Sedangkan 5 orang sisannya adalah pemangku kepentingan pelayanan publik di kantor pemerintah kabupaten Gianyar. Pengguna berumur dari $25-53$ tahun.

Tabel 1. Hasil Pengujian User Acceptance Test

\begin{tabular}{|c|c|c|c|c|c|}
\hline \multirow{2}{*}{ No. } & \multirow{2}{*}{ Kolom } & \multicolumn{2}{|r|}{ Pengujian } & \multirow{2}{*}{$\begin{array}{c}\text { Hambatan dan } \\
\text { permasalahan }\end{array}$} & \multirow{2}{*}{ Status } \\
\hline & & Tgl. & Tester & & \\
\hline \multirow[t]{2}{*}{1.} & \multirow[t]{2}{*}{$\begin{array}{l}\text { Submit data } \\
\text { pengaduan }\end{array}$} & \multirow[t]{2}{*}{$26 / 10 / 2018$} & \multirow[t]{2}{*}{ Pengguna } & $\begin{array}{l}\text { GPS tidak } \\
\text { menunjuk ke } \\
\text { lokasi yang } \\
\text { akurat }\end{array}$ & Error \\
\hline & & & & $\begin{array}{l}\text { Posisi lokasi } \\
\text { pengaduan tidak } \\
\text { sesuai dengan } \\
\text { yang } \\
\text { ditunjukkan di } \\
\text { sistem }\end{array}$ & Error \\
\hline 2. & $\begin{array}{l}\text { Melihat } \\
\text { data } \\
\text { pengaduan }\end{array}$ & $26 / 10 / 2018$ & $\begin{array}{l}\text { Pengguna/Admin/Pemangku } \\
\text { kepentingan }\end{array}$ & - & Ok \\
\hline 3. & $\begin{array}{l}\text { Melihat } \\
\text { rangkuman } \\
\text { data } \\
\text { pengaduan }\end{array}$ & $26 / 10 / 2018$ & $\begin{array}{l}\text { Admin/Pemangku } \\
\text { kepentingan }\end{array}$ & $\begin{array}{l}\text { Sebaran data } \\
\text { lokasi } \\
\text { pengaduan tidak } \\
\text { muncul di peta }\end{array}$ & $\begin{array}{l}\text { Error } \\
\text { jaringan } \\
\text { Internet }\end{array}$ \\
\hline
\end{tabular}

Pengujian User Acceptance Test menunjukkan bahwa sistem informasi pengaduan masyarakat sudah memenuhi fungsionalitasnya dengan baik dan benar $95 \%$ pengguna dapat menggunakan sistem dengan baik tanpa kendala apapun, 5\% pengguna mengalami masalah pada layanan berbasis lokasi yang tidak akurat memberikan lokasi, khususnya pada fungsi submit data pengaduan. $20 \%$ petugas pemangku kepentingan mengalami masalah download data lokasi karena koneksi internet, data lokasi adalah seluruh data lokasi pengaduan yang sudah tersimpan dalam sistem, plot data lokasi tidak muncul dalam peta, namun setelah jaringan Internet kembali lancar plot data lokasi berhasil muncul pada peta.

\section{KESIMPULAN}

Untuk mengumpulkan data pengaduan sehingga mendapatkan data yang lebih informatif adalah dengan menggunakan sistem informasi yang dapat mengumpulkan data multimedia dan data layanan berbasis lokasi. Lingkungan kolaboratif(collaborative environment) dapat mewujudkan model Crowdsourcing dengan memberikan dukungan pengumpulan data secara kolektif. Content Management System(CMS) digunakan untuk mengelola pembuatan dan modifikasi konten digital, CMS mendukung banyak pengguna dalam lingkungan kolaboratif dengan menyediakan Collaborative software atau groupware. Konten digital dapat berbentuk multimedia(grafik, foto dll) dan layanan berbasis lokasi menyediakan data lokasi melalui titik koordinat sehingga data yang didapatkan menjadi lebih informatif. 


\section{Daftar Pustaka}

[1] Anofrizen, "Sistem Informasi Pengaduan Masyarakat Program Keluarga Harapan Kota Pekanbaru ( Studi Kasus: Dinas Sosial Dan Pemakaman Kota Pekanbaru )," Ilmiah Rekayasa dan Manajemen Sistem Informasi 3(6): 97-101, 2017.

[2] B. Bob, Content Management Bible. John Wiley \& Sons, 2005.

[3] B. Daren. "Crowdsourcing as a Model for Problem Solving: An Introduction and Cases." Convergence 14(1): 75-90, 2008.

[4] K. Paulsen, Moving Media Storage Technologies: Applications \& Workflows for Video and Media, 2011.

[5] Prasetya, D.Ramdhana, T. Domai, L.I. Mindarti. "Analisis Pengelolaan Pengaduan Masyarakat Dalam Rangka Pelayanan Publik (Studi Pada Dinas Komunikasi Dan Informatika Kota Malang)." Jurnal Administrasi Publik (JAP), 2(1): 1151-58, 2013.

[6] Rakhmawati, N. Aini. "City113: A Mobile Application to Improve Public Participation in Surabaya City Development for Better Governance." Excellence Science in ASEAN, Vol.2, 2016.

[7] R. Bar, Amin, dan M. Maheswaran, "Confidentiality and Integrity in Crowdsourcing Systems." Springer Briefs in Applied Sciences and Technology: 25-37, 2014.

[8] Susanto, T. Dwi, M. M. Diani, dan I. Hafidz, "User Acceptance of E-Government Citizen Report System (a Case Study of City113 App).” Procedia Computer Science, 124: 56068, 2017. 